\title{
Öğretim Materyallerinin Etkililiğini Artırmaya Yönelik Disiplinlerarası Materyal Geliştirme Model Önerisi: DIMAG Modeli
}

\author{
The Suggestion for Disciplinary Material Development Model Aimed at \\ Enhancing the Efficiency of Teaching Materials: Model of DIMAG
}

$\mathrm{DOI}=\underline{10.17556 / \mathrm{jef} .75930}$

\author{
Oğuzhan SEVİM
}

\section{Özet}

$\mathrm{Bu}$ çalışmanın amacı öğretim materyallerinin etkililiğini artırmaya yönelik disiplinlerarası materyal geliştirme model önerisi sunmaktır. $\mathrm{Bu}$ amaç kapsamında ilgili literatür taranarak uzman görüşlerine de başvurulup bir taslak model hazırlanmıştır. Daha sonra bu taslak model Millî Eğitim Müdürlügüünden izin alınan okullarda uygulanmış, katılımcıların görüş, değerlendirme ve önerileri doğrultusunda taslak modelin nihai şekline ulaşılmıştır. Araştırmadan elde edilen sonuçlara göre Disiplinlerarası Materyal Geliştirme Modeli'nin (DİMAG Modeli) çalışma kapsamında hazırlanan öğretim materyallerinin etkililiğini artırmakla birlikte hem öğretmenlerin hem de öğretmen adaylarının düşünme becerileri üzerinde olumlu etkileri olduğu tespit edilmiştir.

Anahtar kavramlar: Öğretim materyali, disiplinlerarası materyal geliştirme, model önerisi.

\begin{abstract}
The aim of this study is to present the suggestion for disciplinary material development model aimed at enhancing the efficiency of teaching materials. In accordance with this purpose, a draft model has been prepared by reviewing the literature and asking expert's opinions. Afterwards, this draft model has been applied in the schools for which the permission has been received from Directorate of National Education and this draft has been finalized in the direction of the opinions, considerations, and offers of the attendants. According to the results of this study, it has been determined that Disciplinary Material Development Model (DIMAG) has enhanced the efficiency of teaching materials prepared for the study and has had positive impacts on thinking skills of both teachers and teacher candidates.
\end{abstract}



suggestion

Keywords: Teaching material, disciplinary material development, model

\section{Giriș}

Etkili bir öğretim sürecinin gerçekleştirilmesinde kullanılan araç ve gereçlere öğretim materyali denilmektedir. Farklı disiplinlerin öğretiminde belirli öğretim materyalleri (laboratuar malzemeleri, bilgisayar yazılımları, haritalar vb.) kullanıldığı gibi tüm disiplinler tarafından kullanılan genel öğretim materyalleri (kitap, yazı tahtası, projeksiyon vb.) de bulunmaktadır. Fakat tüm bu öğretim materyallerinin ortak yönü; öğrenme konularının somutlaştırılmasını sağlamak, öğretim sürecini kolaylaştırmak ve sürecin etkinliğini artırmaktır (Sevim, 2014; Sevim, 2015; Şahin ve Yıldırım, 1999; Şimşek, 2002; Y1ld1z, 2002).

Öğretim materyalleri farklı form ve özelliklere sahip olarak geliştirilirler. Kimi öğretim materyali metinsel, görsel veya işitsel olabildiği gibi, kimisi hem görsel hem de işitsel olabilir. Özellikle bilgisayar teknolojilerinin gelişmesi ve eğitim alanında yaygın olarak kullanılmasıyla birlikte görsel-işitsel materyaller günümüzde daha çok tercih edilmektedir.

Öğretim materyallerinin hazırlanması ve geliştirilmesi sürecinde tasarımcıların veya uzmanların göz önünde bulundurmaları gereken temel hususlar vardır. Bu hususlar bağlamında öğretim materyalinin öğretim programıyla tutarlı, öğrencinin ilgisini çeken ve derse etkin katılımını artıran, öğrencinin düzeyine uygun ve doğru mesajlar içerecek nitelikte olması gerekir (McAlpine ve Weston, 1994). Öğretim materyalinin bu özellikleri hem öğretmenin ders işleyiş sürecini hem de öğrencinin öğrenme durumunu doğrudan etkileyen etkenlerdir.

Öğretim materyalleri belirli öğrenme ihtiyaçlarının karşılanmasında önemli bir role sahiptir. Bundan dolayı öğretim materyallerinin hazırlanması ve geliştirilmesi süreci dikkatle ele alınmalıdır. Öğretim materyalleri geliştirilmeden veya seçilmeden önce öğrenme ihtiyaçlarının iyi analiz edilmiş olması gerekir (Yalın, 1997). Çünkü öğretim materyali kullanmanın temel gerekçesi bu ihtiyaçların karşılanmasıdır. Belirlenen öğrenme ihtiyaçları materyalin tasarım aşamasını da şekillendirici niteliğe sahiptir. Geliştirilen öğretim materyallerinin uygulanması ve değerlendirilmesi ise bu süreci bütünleyen diğer aşama- 
lardır. Tüm bu aşamalarının başarılı bir şekilde tamamlanabilmesi için ise öğretim tasarımcısı olarak öğretmenlerin pedagojik ve içerik bilgilerini bu süreçte etkin bir şekilde kullanabilmeleri beklenir.

Etkili bir öğretim materyalinin hazırlanabilmesi için öğretmenlerin hizmet öncesinde böyle bir eğitimi almış olmaları gerekir. Hizmet öncesi eğitimden geçen öğretmen adayları çevre koşullarından yararlanarak basit, ancak özgün bir materyal geliştirmeyi, dönem ödevi olarak ya da dönem projesi olarak Öğretim Teknolojileri ve Materyal Geliştirme (ÖTMG) dersinde sunmaktadırlar (Demirel, Seferoğlu, Yağc1, 2001; Küçükahmet, 1999). Fakat bu projeler genellikle üniversite ortamında hazırlanıp sınıfta paylaşılmaktadır. Her ne kadar yaparak-yaşayarak öğrenme süreci olarak görünse de öğretmen adayları bu öğretim materyallerini gerçek öğrenme ortamında hazırlamamaktadırlar. Öğretmen adayları ÖTMG dersinde öğretim materyali hazırlama işlemini hedef kitleyi yani öğrenci grubunu hayal ederek ögrencilerle ilgili herhangi bir analiz veya değerlendirme yapmadan rastgele gerçekleştirmektedirler. Geliştirdikleri öğretim materyallerini ise yine gerçek öğrenme ortamında değil, üniversitedeki sınıf ortamında uygulamaktadırlar. Ayrıca öğretmen adayları tüm bu süreci yaşarken farklı disiplinlerle herhangi bir iş birliğinde bulunmamaktadırlar (Sevim, 2014). Oysa yapılan araştırmalarda hizmet öncesi öğretmen eğitiminde disiplinlerarası iş birlikli materyal geliştirme çalışmalarının başarılı sonuçlar verdiği tespit edilmiştir (Sevim, 2013; Sevim, 2014; Sevim, 2015). Çünkü disiplinlerarası çalışmalar, mevcut yöntemlerle yapılan çalışmaların yerini almak için değil, bu çalışmaları tamamlayıp daha verimli bir hâle getirmek için gerçekleştirilmektedir (Cluck, 1980; Ellis ve Fouts, 2001; Gür, 2003). $\mathrm{Bu}$ bağlamda farklı disiplinlerden yararlanmanın öğretim materyali hazırlama sürecinde konu alanı uzmanı olarak öğretmenlerin başarılı olmalarında önemli bir etken olarak görülmektedir.

Lisans eğitimi süresince öğretim materyali tasarımı ve geliştirme çalışmalarının gerçek öğrenme ortamı olan ilk ya da ortaokulların dışında yapılması öğretmen adaylarının pedagojik becerilerinin istenen düzeyde geliştirilememesine ve eğitim sürecinin verimliliğin düşük olmasına yol açmaktadır. Bu da fakültede öğretim materyali tasarımı ve geliştirmeyle ilgili öğrenilen bilgilerin gerçek hayatta karşılaşılan sorun ya da güçlüklerin çözümüne aktarılması ihtiyacını 
doğurmaktadır. Bunun yanında Yapılandırmacı Öğrenme Yaklaşımı'nın gereklilikleri de göz önünde bulundurulduğunda bu tür uygulamaların gerçek öğrenme ortamında yapılmasının daha etkin sonuçlar alınmasında önemli bir etken olduğunu göstermektedir (Coşkun Diker ve Demirel, 2009). İşte tüm bu ihtiyaç ve gereklilikler neticesinde eğitim ortamlarında disiplinlerarası yaklaşım gittikçe önem kazanmaktadır.

Yapılan bu araştırmada öğretim materyallerinin etkililiğini artırmaya yönelik bir disiplinlerarası materyal geliştirme model önerisi sunulmaya çalışılmıştır. $\mathrm{Bu}$ amaç doğrultusunda şu araştırma sorularına cevap aranmıştır:

$\checkmark$ Geliştirilmek istenen disiplinlerarası materyal geliştirme modeli (DİMAG Modeli) hangi süreçlerden oluşmalıdır?

$\checkmark$ DİMAG Modeli doğrultusunda geliştirilen öğretim materyallerinin etkililiği hangi düzeydedir?

$\checkmark$ Öğretmen adaylarının ve öğretmenlerin DİMAG Modeli ile ilgili görüşleri nelerdir?

\section{Yöntem}

Çalışmanın bu bölümünde araştırmanın deseni, araştırmacı ve katılımcıların rolü, veri toplama araçları, verilerin toplanması ve analizi, araştırmanın gerçekleştirilme işlemlerine ilişkin bilgilere yer verilmiştir.

\section{Araștırma Deseni}

Araştırmanın hem nitel hem de nicel boyutu olduğu için çalışma, bir karma yöntem çeşidi olan keşfedici sıralı desene uygun olarak gerçekleştirilmiştir. Karma yöntem araştırması, bir çalışmada araştırma problemini daha iyi ve derinlemesine anlayabilmek için verilerin toplanması ve analizi süreçlerinde nitel ve nicel yöntemlerin bir arada kullanılmasıdır (Creswell ve Plano Clark, 2014; Hesse-Biber, 2010). Karma yöntem araştırmalarının açıklayıcı sıralı desen, keşfedici sıralı desen, sıralı dönüşümsel desen, eşzamanlı üçgenleme deseni, eşzamanlı iç içe geçmiş desen, eşzamanlı dönüşümsel desen (Creswell, 2003) şeklinde çeşitleri vardır. Keşfedici desen, katılımcılar tarafindan nitel yöntemlerle oluşturulan olguların arasındaki benzerlik ve ilişkilerin nicel olarak ifade edilebilmesi bakımından önemli bir 
araştırma yöntemi olarak görülmektedir (McMillan ve Schumacher, 2006). Keşfedici desenin bu özellikleriyle yapılamak istenen bu çalışmanın özelliklerinin örtüşmesinden dolayı araştırmada keşfedici sıralı desen kullanılmıştır.

Keşfedici sıralı desenin işleyiş süreci genel olarak Şekil 1'deki gibidir:
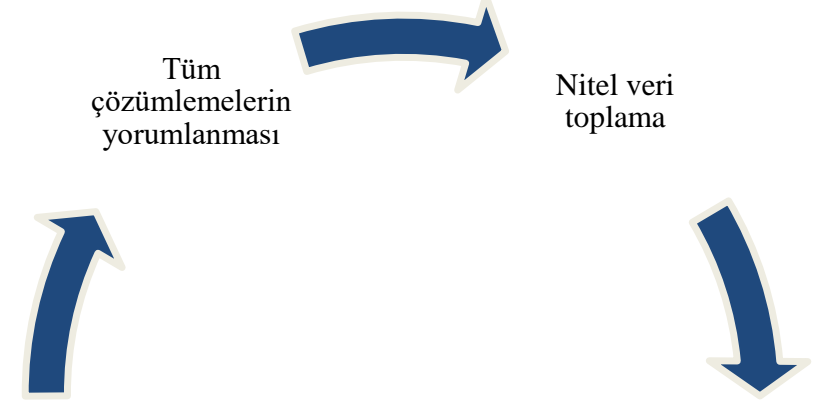

Nicel veri analizi

Nitel veri analizi

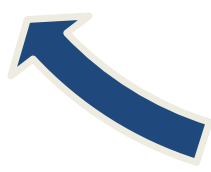

Nicel veri toplama

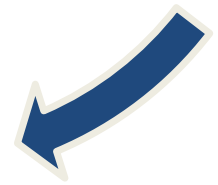

Şekil 1. Keşfedici sıralı desenin işleyiş süreci

Şekil 1'de gösterilen işleyiş sürecine göre bu araştırmada gerçekleştirilen işlemlerin şematik görüntüsü Şekil 2'de gösterilmiştir: 


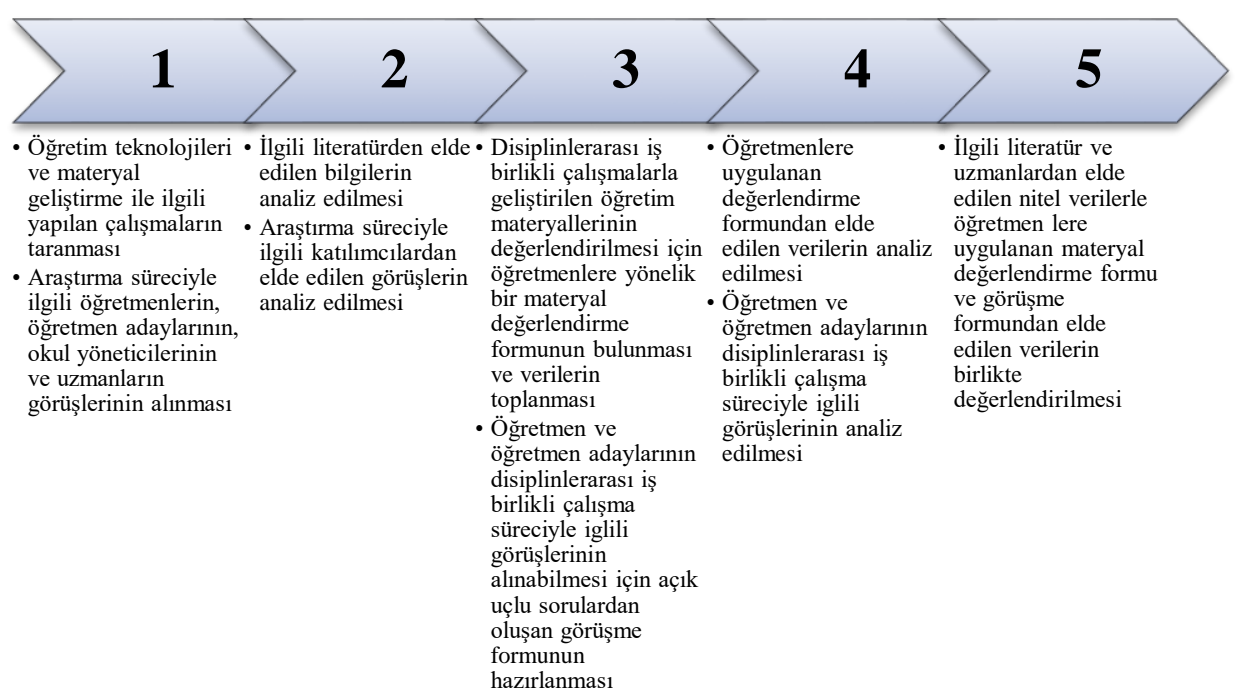

Şekil 2. Araştırma Sürecinin İşlem Basamakları

Şekil 2'de görüldüğü gibi ilk iki basamak araştırmanın nitel boyutunu, üç ve dördüncü basamaklar nicel boyutunu ifade etmektedir. Araştırmanın son basamağında ise elde edilen tüm nitel ve nicel veriler birlikte değerlendirilerek öneride bulunulan materyal geliştirme modelinin etkililiği tespit edilmeye çalışılmıştır.

\section{Çalışma Grubu}

Araştırma karma yöntem desenlerinden biri olan keşfedici desene göre yürütüldüğü için nitel ve nicel aşamalarında farklı katılımcılar yer almıştır. Araştırmanın ilk aşaması olan nitel boyutunda araştırmaya katkı sunacağı düşünülen öğretmenlerin, öğretmen adaylarının, okul yöneticilerinin ve öğretim üyelerinin görüşleri alınmıştır. Nitel boyutla ilgili katılımcıların özellikleri Tablo 1'de gösterilmiştir: 
Ŏguzhan Sevim / EÜ Ĕ̈itim Fakültesi Dergisi, 18-2 (2016), 1275-1301

Tablo 1: Araştırmanın Nitel Boyutunda Yer Alan Katılımcılar

\begin{tabular}{llcccc}
\hline & & $\begin{array}{c}\text { Öğretmen } \\
\text { adayı }\end{array}$ & Öğretmen & Yönetici & $\begin{array}{l}\text { Öğretim } \\
\text { üyesi }\end{array}$ \\
\hline \multirow{2}{*}{ Cinsiyet } & Kadın & 16 & 14 & 3 & 8 \\
& Erkek & 15 & 11 & 9 & 11 \\
& Türkçe Eğitimi & 9 & 10 & 4 & 7 \\
\multirow{4}{*}{ Bölüm } & Çocuk Gelişimi & 8 & 5 & 2 & 3 \\
& Okul Öncesi & 7 & 6 & 3 & 3 \\
& Sinıf Ö̆ğret- & 7 & 7 & 3 & 6 \\
\cline { 2 - 6 } Toplam & menliği & $\mathbf{3 1}$ & $\mathbf{2 8}$ & $\mathbf{1 2}$ & $\mathbf{1 9}$ \\
\hline
\end{tabular}

Araştırmanın nitel boyutunda yer alan öğretmen adayı, öğretmen, yönetici ve öğretim üyesi olmak üzere toplam 90 katılımcıyla disiplinlerarası öğretim materyali geliştirme ve öğretim materyallerinin gerçek öğrenme ortamında tasarımlanması konusunda görüşmeler yapılmış, katılımcıların konuyla ilgili düşünceleri öğrenilmiş ve süreçle ilgili önerileri alınmıştır. Görüşmeler 2013-2014, 2014-2015, 2015-2016, 2016-2017 öğretim yıllarında düzenli olarak yapılmış ve her dönem alınan dönütlerle birlikte disiplinlerarası öğretim materyali geliştirme modeli olan DİMAG Modeli'nin genel çerçevesi çizilmeye çalışılmıştır.

Araştırmanın nitel boyutunda yer alan katılımcılardan yararlanmanın temel amacı, disiplinlerarası materyal geliştirme modeli olan DIMAG Modeli'nin kuramsal bölümünün tamamlanmasında düşünsel desteğin alınmasıdır. İlgili literatürden elde edilen bilgiler ile birlikte nitel katılımcılarla yapılan görüşmeler neticesinde DİMAG Modeli'nin temel basamakları belirlenmeye çalışılmıştır.

Araştırmanın nicel boyutunda ise Erzurum ili Yakutiye ilçesinde bulunan ve farklı sosyoekonomik özelliklere sahip 8'i devlet 2'si özel olmak üzere toplam on okulda DİMAG Modeli'nin uygulamaları gerçekleştirilmiştir. Bu uygulamalara aktif olarak katılan 25 öğretmen ve 110 öğretmen adayı ile ilgili bilgiler Tablo 2'de gösterilmiştir: 
Oğuzhan Sevim / Ë̈ Ĕ̆itim Fakültesi Dergisi, 18-2 (2016), 1275-1301

Tablo 2: Araştırmanın Nicel Boyutunda Yer Alan Katılımcılar

\begin{tabular}{llcc}
\hline & & Öğretmen adayı & Öğretmen \\
\hline \multirow{2}{*}{ Cinsiyet } & Kadın & 85 & 16 \\
& Erkek & 75 & 11 \\
& Türkçe Eğitimi & 100 & 12 \\
\multirow{3}{*}{ Bölüm } & Çocuk Gelişimi & 60 & - \\
& Okul Öncesi & - & 4 \\
& Sinıf Öğretmenliği & - & 9 \\
\hline \multirow{2}{*}{ Toplam } & & $\mathbf{1 6 0}$ & $\mathbf{2 5}$ \\
\hline
\end{tabular}

Araştırmanın nicel boyutunda yer alan öğretmen adayları temel dil becerilerinin öğretimine yönelik geliştirilen öğretim materyallerinin ihtiyaç analizi, tasarım, geliştirme, uygulama ve değerlendirme süreçlerinde rol alırken öğretmenler ise uygulama ve değerlendirme süreçlerinde gözlemci ve rehber olarak rol almışlardır.

\section{Verilerin Toplanması ve Analizi}

Araştırmada nitel ve nicel olmak üzere iki tür veri toplama süreci yaşanmıştır. Çalışmanın nitel boyutunda doküman analizi tekniği ile yarı yapılandırılmış görüşme tekniği kullanılırken nicel boyutunda Öğretim Materyali Değerlendirme Formu, Öğretmen Adaylarının DİMAG Modeli'ne İlişkin Görüş Formu ve Öğretmenlerin DİMAG Modeli'ne İlişkin Görüş Formu kullanılmıştır.

\section{Doküman Analizi Tekniği}

Araştırma sorularından ilki olan "Geliştirilmek istenen disiplinlerarası materyal geliştirme modeli (DİMAG Modeli) hangi süreçlerden oluşmalıdır?" sorusuna cevap bulabilmek için konuyla ilgili yapılmış çalışmalara elektronik ve basılı dergiler, kütüphane katalogları, yayın tarama indeksleri, ulusal tez merkezi aracılığıyla ulaşılmaya çalışılmıştır. Yayın tarama sürecinde öğretim materyali, materyal geliştirme, disiplinlerarası çalışma, teaching material, material development, interdisciplinary study gibi anahtar kavramlar kullanılmıştır.

\section{Yarı Yapılandırılmış Görüşme Tekniği}

Araştırma sorularından ilki olan "Geliştirilmek istenen Disiplinlerarası Materyal Geliştirme Modeli (DIMAG Modeli) hangi süreçlerden oluşmalıdır?" sorusuna yanıt aramak için Yakutiye ilçesinde bulunan okullarda görev yapan yöneticiler, öğretmenler ve eğitim fakültesinde 
öğrenim gören öğretmen adayları ile görev yapan öğretim üyeleriyle görüşmeler yapılmıştır.

Araştırmanın birinci sorusu kapsamında yapılan görüşmelerde, doküman analizi tekniğinden hareketle araştırmacı tarafından belirlenen sorular katılımcılara yöneltilmiştir. Katılımcılara yöneltilen soruların ana teması şu şekilde sıralanabilir:

$\checkmark$ Eğitim fakültelerinden yürütülen Öğretim Teknolojileri ve Materyal Tasarımı derslerindeki bilgi ve becerilerin okullara yansima durumu

$\checkmark$ Öğretim Teknolojileri ve Materyal Geliştirme derslerinde edilen bilgi ve becerilerin gerçek öğrenme ortamına aktarılmasında tespit edilen eksiklikler veya problemler

$\checkmark$ Tespit edilen eksikliklerin tamamlanmasına ya da problemlerin çözümlenmesine yönelik görüş ve öneriler

$\checkmark$ Eğitim fakülteleri ile Millî Eğitime bağlı okulların iş birlikli olarak disiplinlerarası materyal geliştirme projelerinin nasıl yapılabileceği ile ilgili görüş ve öneriler

Görüşmeler 2013-2014, 2014-2015, 2015-2016, 2016-2017 öğretim yıllarında düzenli olarak yapılmış ve görüşmelerden elde edilen veriler dört y1l boyunca kaydedilerek bir sonraki döneme bu veriler doğrultusunda hazırlanılmıştır. Her dönem elde edilen verilerin analizinde ise nitel araştırmalarda kullanılan içerik analiz tekniği kullanılmıştır.

\section{Öğretim Materyali Değerlendirme Formu}

Araştırma sorularından ikincisi olan "DİMAG Modeli doğrultusunda geliştirilen öğretim materyallerinin etkililiği hangi düzeydedir?" sorusuna cevap bulabilmek için Öğretim Materyali Değerlendirme Formu kullanılmıştır. Materyal değerlendirme formunda yer alan maddeler, ilgili alan yazın taranarak elde edilen form örnekleri incelenip gerekli ekleme ve çıkarmalar yapılarak belirlenmiştir. Formda yer alan maddelerle ilgili olarak bir ölçme-değerlendirme ve bir de Türkçe Eğitimi alan uzmanına müracaat edildikten sonra forma nihai şekli verilmiştir. Nihai form 18 maddeden oluşmuştur. Nihai formdan alınacak en düşük puan 18 iken en yüksek puan 90'dır. Formun puanlandırılması ise çok kötü (1), kötü (2), idare eder (3), iyi (4), çok iyi (5) olarak derecelendirilmiştir. Formdan elde edilen verilerin değer- 
lendirilmesinde ise betimsel ve kestirimsel istatistiksel işlemler kullanılmıştır.

Öğretmen ve Öğretmen Adaylarının DIMAG Modeli’ne Ilişkin Görüş Formu

Araştırmanın üçüncüsü sorusu olan “Öğretmen adaylarının ve öğretmenlerin DİMAG Modeli ile ilgili görüşleri nelerdir?" sorusuna yanıt bulabilmek için Öğretmen Adaylarının DİMAG Modeli’ne İlişkin Görüş Formu ile Öğretmenlerin DİMAG Modeli'ne İlişkin Görüş Formu kullanılmıştır. İlgili literatür tarandıktan ve disiplinlerarası materyal geliştirme süreciyle ilgili görüşmeler yapıldıktan sonra elde edilen veriler doğrultusunda hem öğretmenlerin hem de öğretmen adaylarının süreçle ilgili görüşlerinin öğrenilebilmesi için beş soru hazırlanmış, Türkçe Eğitimi alan uzmanlarının ve süreci yakından takip eden yöneticilerin de görüşleri alındıktan sonra bu beş sorudan ikisi elenmiş ve geriye kalan üç soru DİMAG Modeli'ne göre materyal geliştirme sürecine katılan öğretmen ve öğretmen adaylarına yöneltilmiştir. Görüşme formlarından elde edilen verilerin analizinde ise içerik analizi tekniği kullanılmıştır.

\section{İşlem}

Öğretim materyallerinin etkililiğini artırmaya yönelik bir disiplinlerarası materyal geliştirme model önerisi sunulmaya çalışılan bu araştırmada takip edilen işlem basamakları şu şekildedir:

> İlgili alan yazın taraması: DİMAG Modeli’nin aşamalarının belirlenebilmesi için öncelikle ilgili alan yazın taranarak bir veri envanteri oluşturulmuş ve bu envanter üzerinde derinlemesine çalışılmıştır.

Öğretmenlerin, öğretmen adaylarının, okul yöneticilerinin ve uzmanların DİMAG Modeli’nin taslağıyla ilgili görüşlerinin alınması: DIMAG Modeli'nin aşamalarının belirlenebilmesi için öncelikle bir taslak model hazırlanmış, bu taslak modelle ilgili konuyla ilgili uzmanların görüşleri alınmıştır.

DİMAG Modeli’nin aşamalarının belirlenmesi: Konuyla ilgili uzmanların görüşleri alınıp gerekli düzeltmeler ve eklemeler yapıldıktan sonra DİMAG Modeli'nin aşamaları belirlenmiştir. 
Araştırmanın katılımcılarının belirlenmesi: Araştırma sürecine kimlerin katılacağı amaçlı örnekleme tekniğiyle belirlenmiş ve katılımcı grupların süreçteki rolleri açıklanmıştır.

> Millî Eğitim Müdürlüğünden gerekli izinlerin alınması: Okullarda yapılacak uygulamalarda resmî izin sıkıntısı yaşanmaması için uygulama öncesinde Yakutiye İlçe Millî Eğitim Müdürlüğünden uygulamalar için izin alınmıştır.

$>$ Uygulama yapılacak okulların belirlenmesi: Millî Eğitim Müdürlüğünden izin alındıktan sonra bu okullar içerisinden materyal geliştirme işlemlerinin yürütülmesi için random usulü on okul belirlenmiştir.

$>$ Deney ve kontrol gruplarının belirlenmesi: Materyal geliştirme sürecinde yer alan üç grup vardır. Bunlardan ikisi Türkçe Eğitimi Bölümünde, biri ise Çocuk Gelişimi Bölümünde öğrenim gören öğrencilerden oluşmaktadır. Türkçe Eğitimi ikinci sınıf A şubesinde öğrenim gören ve Çocuk Gelişimi ikinci s1nıf gece öğretiminde öğrenim gören öğrenciler araştırmanın deney grubunu, Türkçe Eğitimi ikinci sınıf B şubesinde öğrenim gören ögrenciler ise kontrol grubunu oluşturmuştur.

$>$ Deney ve kontrol gruplarında iş birlikli çalışma gruplarının oluşturulması: Hem deney gruplarında hem de kontrol grubunda iş birlikli çalışma grupları oluşturularak her bir iş birlikli çalışma grubundan bir öğretim materyali geliştirmeleri istenmiştir. Bu şekilde kontrol grubunda 10 iş birlikçi çalışma grubu, deney grubunda ise 10 disiplinlerarası iş birlikli çalışma grubu olmak üzere hem deney hem de kontrol grubunda toplam 20 iş birlikli çalışma grubu oluşturulmuştur.

> Deney grubunda disiplinlerarası iş birlikli çalışacak grupların eşleştirilmesi: Deney gruplarının her birinde iş birlikli çalışma grupları belirlendikten sonra bu gruplar disiplinlerarası materyal geliştirecekleri için Türkçe Eğitimi Bölümünde öğrenim gören her bir iş birlikli çalışma grubu ile Çocuk Gelişimi Bölümünde öğrenim gören bir iş birlikli çalışma grubu eşleştirilmiştir. Eşleştirilen bu gruplar ihtiyaç analizi doğrultusunda belirlenen ortak bir proje üzerinde çalışıp materyal hazırlamışlardir. 
Materyal geliştirme ve uygulama süreci: Yapılan bu araştırmada deney grubunda yer alan Türkçe Eğitimi Bölümü öğrencileriyle çocuk gelişim bölümü öğrencileri disiplinlerarası iş birlikli çalışma modeli olan DİMAG Modeli'nin açıklanan aşamalarına uygun olarak öğretim materyalleri geliştirerek uygulamışlardır. Kontrol grubunda ise Türkçe Eğitimi Bölüm öğrencileri dersin mevcut müfredatına göre çalışarak öğretim materyalleri geliştirmişlerdir. Geliştirdikleri bu öğretim materyallerini uygulama okullarında uygulayarak elde ettikleri verileri değerlendirilmek üzere arşivlemişlerdir.

> Geliştirilen materyallerin değerlendirilmesi: Geliştirilen materyaller hem kontrol hem de deney gruplarındaki iş birlikli çalışma grupları tarafından gerçek öğrenme ortamında uygulanıp raporlandıktan sonra araştırmanın yöneticisine teslim edilmiştir. Deney ve kontrol gruplarında iş birlikli olarak çalışan araştırma gruplarının geliştirmiş oldukları her bir öğretim materyali, öğretim materyallerinin uygulanma süreci boyunca gözlemler yapan 10 Türkçe öğretmeni, 5 çocuk gelişimi uzman1, 7 okulöncesi öğretmeni, 8 sınıf öğretmeni olmak üzere toplam 30 öğretmen tarafindan değerlendirilmiştir. Deney ve kontrol grupları tarafından hazırlanan her bir öğretim materyaline öğretmenler tarafından verilen puanların ortalaması alınmiştır.

Deney ve kontrol gruplarına ait materyal değerlendirme puanlarının karşılaştırılması: Kontrol ve deney gruplarına ait ortalama başarı puanları Mann Whitney U testi ile karşılaştırılmış ve aradaki fark yorumlanmıştır.

> Öğretmen ve öğretmen adaylarının DİMAG Modeli’ne ilişkin görüşlerinin alınması: Materyal geliştirme ve uygulama süreçleri tamamlandıktan sonra sürece katılan öğretmen ve öğretmen adaylarının DİMAG Modeli'ne ilişkin görüşleri alınmıştır.

Süreç değerlendirme ve tartışma: Süreç boyunca elde edilen tüm nitel ve nicel veriler değerlendirilmiş, ilgili literatür bağlamında tartışılmıştır. 


\section{Bulgular}

Çalışmanın bu bölümünde araştırma sorularını yanıtlayabilmek için elde edilen verilerin analiziyle ulaşılmış bulgulara yer verilmiştir.

\section{Birinci Araştırma Sorusuna Yönelik Elde Edilen Bulgular}

İlgili literatür incelenip elde edilen veriler doğrultusunda konunun uzmanlarının da görüşü alınarak bir disiplinlerarası materyal geliştirme modeli olan DİMAG Modeli'nin aşamaları belirlenmiş ve aşağıdaki gibi ifade edilmiştir:

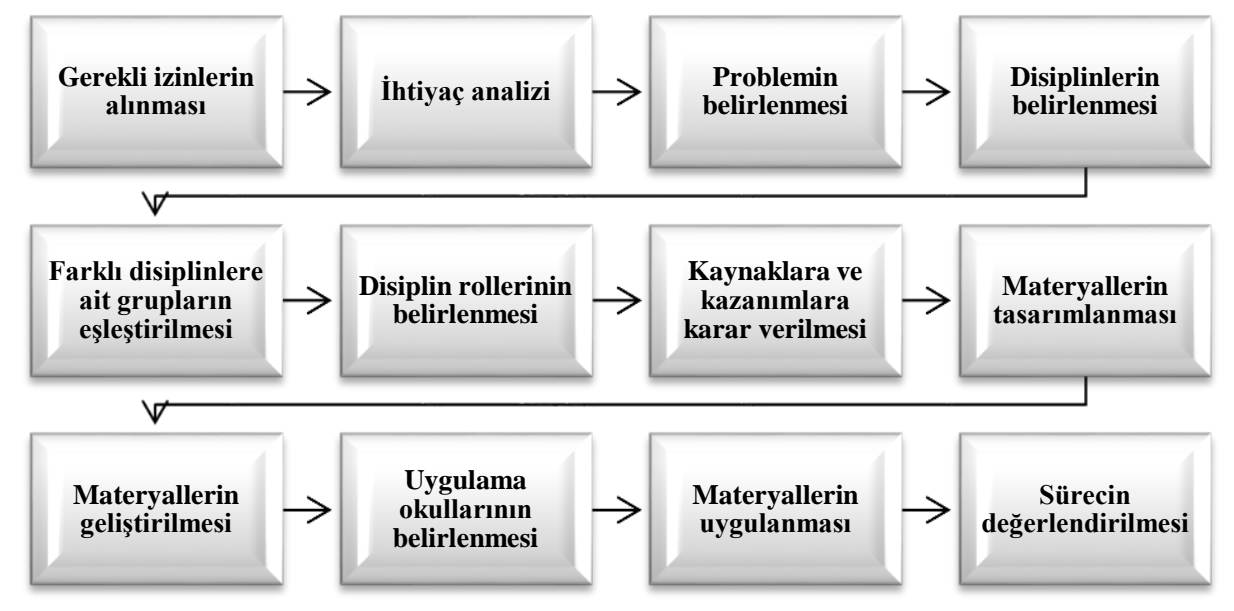

Şekil 3: DİMAG Miodeli'nin Aşamaları

DİMAG Model'nin işlem basamaklarıyla ilgili açıklamalar şu şekildedir:

1. Gerekli izinlerin alınması: Eğitim Fakültesi Öğretmen Yetiştirme Lisans Programları'nda yer alan ders tanımına göre Öğretim Teknolojileri ve Materyal Tasarımı Dersi fakülte bünyesinde yürütülen bir derstir. Bu dersin gerçek öğrenme ortamında yürütülebilmesi için Millî Eğitim Müdürlüklerinden gerekli izinlerin alınması gerekmektedir.

2. İhtiyaç analizi: DİMAG Modeli'nin ikinci basamağı olan ihtiyaç analizinde temel alan uzmanı olan öğrenciler (bu çalışmada Türkçe Eğitimi Bölümü öğrencileri) tarafından Millî Eğitim Müdürlüğü’nden izin alınan okullarda hedef kitlenin öğrenme ihtiyaçları tespit edilir. 
Temel alan uzmanı ve yardımcı alan uzmanı kavramlarının iyi anlaşılması gerekir. Geliştirilecek öğretim materyali hangi alan ile ilgili hazırlanıyorsa o alanın uzman gruplarına temel alan uzmanları denilmektedir. $\mathrm{Bu}$ durumda diğer disiplinlerarası iş birlikli gruplara da yardımcı alan uzmanları denilmektedir.

3. Problemin belirlenmesi: Hedef kitleye yönelik gerçekleştirilen ihtiyaç analizi çalışmalarından sonra araştırmanın problemi net bir şekilde ortaya konulur.

4. Sürecine katılacak olan disiplinlerin belirlenmesi: Hedef kitlenin öğrenme problemlerine göre temel alan uzmanlarının (bu çalışmada Türkçe Eğitimi Bölümü öğrencileri) iş birlikli çalışacakları diğer disiplinler yani yardımcı alan uzmanları (bu çalışmada Çocuk Gelişimi Bölümü öğrencileri) belirlenir. Süreçte birden fazla disiplin yer alabilir.

5. Farklı disiplinlere ait grupların eşleştirilmesi: Farklı disiplinlere ait gruplar iş birlikli çalışarak ortak bir materyal geliştirecekleri için bu grupların eşleştirilmesi gerekir. Örneğin Türkçe eğitimi alan uzmanları kendi içerisinde 10 farklı gruba, çocuk gelişimi alan uzmanları kendi içerisinde 10 farklı gruba ayrıldıktan sonra her iki uzmanlığın bu on farklı grubu birbiriyle eşleştirilir. Böylece süreçte etkili bir iş birlikli çalışma tarzı sağlanabilir. Materyal geliştirme sürecinde yer alacak disiplinler belirlendikten ve farklı disiplinlere ait gruplar eşleştirildikten sonra bu disiplinlerin araştırmanın hangi sürecinde ne gibi sorumlulukları üstleneceğiyle ilgili görev dağılımına geçilir.

6. Bütünleştirilen disiplin rollerinin belirlenmesi: $\mathrm{Bu}$ aşamada araştırmada hangi disiplinler yer alacaksa bu disiplinlerin materyal geliştirme sürecindeki rolleri belirlenir. Örneğin temel dil becerilerinin öğretimine yönelik hazırlanılması düşünülen bir öğretim yazılımının geliştirilebilmesi için Türkçe eğitimi alan uzmanlarının bilişim teknologlarından yardım almaları gerekir. Yani Türkçe eğitimi alan uzmanlarıyla bilişim teknolojileri alan uzmanları disiplinlerarası iş birlikli çalışarak bu ögretim yazılımını geliştireceklerdir. Bu süreçte hem Türkçe eğitimi alan uzmanlarının hem de bilişim teknolojileri alan uzmanlarının görevlerinin ya da rollerinin netleştirilmesi gerekmektedir. 
7. Süreçte kullanılacak kaynaklara ve programdan hareketle öğrenme kazanımlarına karar verilmesi: $\mathrm{Bu}$ aşamada farklı disiplinlerden bir araya gelen uzman gruplar, eğitim önceliklerini belirleme ve öğretim sürecini şekillendirmek için başvuracakları kaynakları belirlerler. Bunun yanında öğretim amaçlarının gerçekleşip gerçekleşmediğinin anlaşılabilmesi için de öğrenme kazanımlarını netleştirirler.

8. Kazanımları karşılamak üzere materyallerin tasarımlanması: $\mathrm{Bu}$ aşamada disiplinlerden bir araya gelen uzman gruplar kararlar alırlar. Bu kararlar arasında öğretim materyalinin nasıl uygulanacağı, materyalin öğrenme içeriğinin nelerden oluşacağı, uygulama sürecinin başarılı olup olmadığının anlaşılabilmesi için kullanılacak ölçme araçları gibi ögeler yer alır.

9. Tasarımlanan materyallerin geliştirilmesi: Bu aşamada uzman gruplar tasarım aşamasında aldıkları kararlar doğrultusunda öğretim materyalini geliştirirler. Materyalin geliştirilmesi aşamasında dikkat edilecek en önemli husus materyalin uygulama kılavuzunun hazırlanmasıdır. $\mathrm{Bu}$ kılavuz çeşitli değişkenler açısından birbirinden farklılık gösteren öğrenci ve öğretmenlere materyalle ilgili açıklayıcı bilgiler sunmalidır.

10. Uygulama okullarının belirlenmesi: Milli Eğitim Müdürlüklerinden gerekli izinler alındıktan sonra hangi okullarda uygulama yapılaması planlanıyorsa, o kullara gidilip yönetici ve öğretmenlerle ön görüşmeler yapılmalıdır.

11. Geliştirilen materyallerin uygulanması: $\mathrm{Bu}$ aşamada öncelikle uzman gruplar tarafından bir uygulama planının hazırlanması gerekir. Yani öğretim materyali ne zaman ve ne kadar sürede nasıl uygulanacağı açıkla belirtilmelidir. Hazırlanan öğretim materyalinin öğretmenler tarafından nasıl kullanılacağı öğretmenlere tüm boyutlarıyla açıklanmalıdır. Bu materyalin başarılı bir şekilde uygulanabilmesi için gerekli olan ortam özellikleri varsa bunların sağlanması için uzman gruplar tarafından okul yönetimine uyarılarda bulunulması gerekir.

12. Sürecin değerlendirmesi: DIMAG Modeli'nde değerlendirme işlemi hem süreç hem de ürün değerlendirmesi şeklinde karşımıza çıkmaktadır. Süreç değerlendirmesi, öğretim materyalinin 
geliştirilmesi sürecindeki tüm aşamalarda yapılmalıdır. Her tamamlanan aşamada o zaman dilimine kadar yapılan tüm eğitsel işlemler göz geçirilerek değerlendirilir. Bu şekilde gerçekleştirilen bir değerlendirme süreciyle ileriki süreçlerde yaşanması muhtemel problemler en aza indirilmiş olur. Ürün değerlendirmede ise geliştiren materyalin türü, değerlendirme ölçütleri üzerinde etkili olacaktır. Yazılı, görsel, işitsel, görsel-işitsel, bilgisayar yazılımı gibi farklı türlerdeki öğretim materyallerinin değerlendirilmesindeki temel ölçüt materyalin, öğrenme kazanımlarının gerçekleşmesine sağladığı katkıdır. Uzman gruplar bir araya gelerek hazırlanan öğretim materyalinin niteliğine uygun olarak bir değerlendirme formu hazırlayarak değerlendirme işlemlerini yaparlar.

\section{İkinci Araştırma Sorusuna Yönelik Elde Edilen Bulgular}

Araştırmanın bu bulgu başlığında kontrol ve deney gruplarına ait ortalama başarı puanları Mann Whitney U testi ile analiz edilmiş ve elde edilen sonuçlar Tablo 3'te gösterilmiştir.

Tablo 3. Kontrol Ve Deney Gruplarına Ait Ortalama Başarı Puanlarının Karşılaştırılması

\begin{tabular}{lllll}
\hline & $\mathbf{N}$ & Ort. & U & p \\
\hline Kontrol & 10 & 66,10 & 11,50 & 0,00 \\
Deney & 10 & 76,30 & & \\
\hline
\end{tabular}

Tablo 3'e bakıldığında kontrol grubuna ait ortalama başarı puanı 66,10 ; deney grubuna ait ortalama başarı puanının ise 76,30 olduğu görülmektedir. Gruplar arasında yaklaşık 10 puan fark bulunmaktadır. Mann Whitney U testi sonuçlarına göre deney grubu lehine anlamlı bir farkın olduğu anlaşılmaktadır. Yani yapılan değerlendirme sonuçlarına göre DİMAG Modeli'nin uygulandığı deney grubunda geliştirilen ögretim materyalleri, kontrol grubunda geliştirilen öğretim materyallerinden daha başarı görülmüştür.

\section{Üçüncü Araştırma Sorusuna Yönelik Elde Edilen Bulgular}

Araştırmanın bu bulgu başlı̆̆ında öğretmenlere ve öğretmen adaylarına DİMAG Modeli ile ilgili görüşleri sorulmuş ve elde edilen veriler içerik analizi tekniğiyle çözümlenerek tablolar hâlinde ifade edilmiştir.

Öğretmen ve öğretmen adaylarının görüşmenin ilk sorusu olan “DİMAG Modeli'nin öğretim materyali geliştirme sürecine yenilik 
sunduğunu düşünüyor musunuz? Cevabınız evet ise bunlar nelerdir?" sorusuna verdikleri cevaplar analiz edilmiş ve Tablo 4'teki bulgular elde edilmiştir.

Tablo 4. Birinci Görüşme Sorusuna Verilen Cevaplar

\begin{tabular}{lcc}
\hline & Öğretmen adayı & $\begin{array}{c}\text { Öğretmen } \\
\boldsymbol{f}\end{array}$ \\
\hline İş birlikli çalışma olanağı sunması & 72 & 17 \\
Disiplinlerarası çalışma olanağı sun- & 65 & 23 \\
ması & 59 & 22 \\
Gerçek öğrenme ortamında yapılması & 43 & 15 \\
Fakülte ile okulu bütünleştirmesi & 38 & 3 \\
Sistematik bir yaklaşım olması & 30 & 1 \\
İlkelerinin açık ve kolay anlaşılır ol- & 27 & - \\
ması & 18 & 7 \\
Esnek bir yapıya sahip olması & 13 & 2 \\
\hline Tüm beceri alanlarına hitap etmesi & & \\
Proje tabanlı çalışmaları içermesi & & \\
\hline
\end{tabular}

Görüşmenin ilk sorusuna verilen cevaplara bakıldığında öğretmen adaylarının ve öğretmenlerin DİMAG Modeli'nin özellikle iş birlikli ve disiplinlerarası çalışmalara olanak tanıması ve gerçek öğrenme ortamında yapılması açısından öğretim materyali geliştirme sürecine yenilik sunduğunu düşündükleri anlaşılmaktadır. Tablo 4'e göre öğretmen adayları DİMAG Modeli'nin sıklıkla iş birlikli çalışmalara olanak tanıması üzerinde dururken öğretmen adaylarının disiplinlerarası çalışmalara olanak tanıması üzerinde durdukları görülmektedir.

Konuyla ilgili olarak öğretmen adayı olan Katılımcı (ÖAK) 15'in görüşleri şu şekildedir:

Bence ögretim materyalleri iş birlikli geliştirilmeli. Çünkü ben yalnız çalıştı̆̆ımda tüm bu süreci tam anlamıyla planlayıp yürütmekte yetersiz kalırım. Yani kesinlikle iş bölümü olmall. Bu yüzden DIMAG Modeli iş birlikli çalışmak açısından bence etkili bir model. (ÖAK 15)

Yine birinci araştırma soruyla ilgili olarak öğretmen olan Katılımcı (ÖK) 13'ün görüşleri şu şekildedir:

Lisans döneminde bu dersi biz de almıştık. Tüm uygulamalarımızı kendi sinıfimızda yaptı. Gelişstirdiğimiz materyaller de genellikle hep dil bilgisinin ögretimine yönelik araçlar ve çok basitlerdi. Ama bu uygulamaya baktığımda hem bölümler arasında hem de ögrenciler arasında bir iş birliğinin olduğunu ve uygulamaların 
fakülte dışındaki okullarda yapıldığını görüyorum. Önce biraz karmaşılk gibi gelse de bence çok etkili bir yol. (ÖAK 13)

ÖAK 15 ve ÖK 13'ün birinci araştırma sorusuna verdikleri cevaplara bakıldığında özellikle iş birlikli çalışma, iş bölümü yapma, gerçek öğrenme ortamında uygulama ve disiplinlerarası çalışmanın öneminden bahsettikleri anlaşılmaktadır.

Öğretmen ve öğretmen adaylarının görüşmenin ikinci sorusu olan "DİMAG Modeli'nin mesleki becerilerin geliştirilmesine katkı sağladığını düşünüyor musunuz? Cevabınız evet ise bunlar nelerdir?" sorusuna verdikleri cevaplar analiz edilmiş ve Tablo 5 'teki bulgular elde edilmiştir.

Tablo 5. İkinci Görüşme Sorusuna Verilen Cevaplar

\begin{tabular}{lcc}
\hline & $\begin{array}{c}\text { Öğretmen adayı } \\
\boldsymbol{f}\end{array}$ & $\begin{array}{c}\text { Öğretmen } \\
\boldsymbol{f}\end{array}$ \\
\hline Disiplinlerarası çalışma becerisi & 69 & 23 \\
Planlı ve programlı çalışma becerisi & 58 & 12 \\
İş birlikli çalışma becerisi & 55 & 15 \\
Problem çözme becerisi & 42 & 7 \\
Yeni öğrenmelere açık olma becerisi & 38 & 8 \\
Öğrenci ve diğer görevlilerle etkili iletişim & 31 & 10 \\
kurma becerisi & 23 & 5 \\
İletişim becerilerini kullanma becerisi & 17 & 2 \\
Esnek düşünme becerisi & 14 & 6 \\
Özel alan bilgisini güncelleme becerisi & 9 & 3 \\
Olasılıklı düşünme becerisi & & \\
\hline
\end{tabular}

Öğretmen ve öğretmen adaylarıyla yapılan görüşmenin ikinci sorusuna verilen cevaplar analiz edildiğinde yine her iki katılımcı grubun da DİMAG Modeli'ni disiplinlerarası, planlı-programlı ve iş birlikli çalışma becerilerini kazandırması açısından öğretmenlik mesleğini geliştirmede etkili olarak gördükleri anlaşılmaktadır.

Konuyla ilgili olarak KÖA 70 ile KÖ 3'ün görüşleri şu şekildedir:

Daha önce yapmış olduğumuz hiçbir proje çalışması disiplilerarası değildi. Illk kez böyle bir çalışmaya katıldım. Sürecin başında grubumuzun başarılı olmasıyla ilgili bazı kaygılarım vardı. Fakat yaşadığım bu süreçte eş grubumuzdaki çalışma arkadaşlarımızdan 
Oğuzhan Sevim / Ë̈ Ĕ̆itim Fakültesi Dergisi, 18-2 (2016), 1275-1301

yeni bilgiler ögrendim. Süreçten benim gibi kaygı duyan arkadaşlarımla birlikte aslında kaygılarımızın yersiz olduğunu anladık. (KÖA 70)

Okulumuza materyal geliştirmek için gelen öğretmen adaylarını her hafta düzenli olarak etkinlikler yaptıklarını gördüm. Bu etkinlikler aşamalı olarak yapıldı. Süreç ilerledikçe sınıfla da kaynaştıklarını ve yaşanan öğrenme güçlüklerini etkili bir şekilde tespit ettiklerine şahit oldum. Öğretmen adayları tüm çalışmalarını sürecin sonuna kadar ellerindeki programa göre yaptılar. (KÖ 3)

Her iki görüşe de bakıldığında katılımcıların özellikle disiplinlerarası ve planlı-programlı çalışmaların etkinliği üzerinde durdukları anlaşılmaktadır. KÖ 3'e göre bu durum öğretmen adaylarının kendi çalışmalarında daha da derinleşmelerine yardımcı olmuştur.

Öğretmen ve öğretmen adaylarının görüşmenin üçüncü sorusu olan "DİMAG Modeli'ne uygun ögretim materyali geliştirme sürecinin bir katılımcısı olarak kendinizi nasıl değerlendirirsiniz?" sorusuna verdikleri cevaplar analiz edilmiş ve Tablo 6'daki bulgular elde edilmiştir.

Tablo 6. Üçüncü Görüşme Sorusuna Verilen Cevaplar

\begin{tabular}{lcc}
\hline & Öğretmen adayı & Öğretmen \\
& $\boldsymbol{f}$ & $\boldsymbol{f}$ \\
\hline Problem çözen & 66 & 8 \\
Stratejik düşünen & 51 & 3 \\
Eleştirel düşünen & 39 & 5 \\
Yansıtıcı düşünen & 28 & 17 \\
Hayalci & 21 & - \\
Yenilikçi & 18 & 4 \\
Kendine güvenen & 13 & 5 \\
Olaylara samimi yaklaşan & 9 & 6 \\
Sorumluluk sahibi & 8 & 13 \\
Disiplinli çalışan & 7 & 4 \\
\hline
\end{tabular}

Araştırmanın üçüncü sorusuna bakıldığında öğretmen ve öğretmen adaylarının DİMAG Modeli'ne göre materyal geliştirme sürecinden sonra kendilerini değerlendirme tarzlarının birbirinden farklılık gösterdiği anlaşılmaktadır. Öğretmen adayları süreçten sonra kedilerini özellikle problem çözen ve stratejik düşünen; öğretmenlerin kendilerini yansıtıcı düşünen ve sorumluluk sahibi bireyler olarak değerlendirmeleri dikkat çekmektedir.

Konuyla ilgili olarak ÖAK 20'nin görüşleri şu şekildedir: 
Bana göre DIMAG Modeli'nin en önemli basamağ problemin belirlenmesidir. Çünkü bu aşamadan sonra yapılan tüm işlemler bu problemin çözümüne dönük olarak yapılmaktadır. Süreçte pek çok problemle karşılaştık. Bize düşen ise bu problemleri aşmaktı. Karşılaştı̆̆ımız her bir problemden sonra böyle bir problem yaşamamak adına adımlarımızı daha dikkatli atmaya başladık. Karşımıza daha ne türlü problemler çıkabilir, bunları düşünmeye başladık. (ÖAK 20)

ÖAK 20'nin görüşlerine bakıldığında materyal geliştirme sürecinde önce problem çözme becerisinin ve karşılaşılan her bir problemden sonra ise stratejik düşünme becerisinin ağırlık kazandığı anlaşılmaktadır. Yani ÖAK 20'nin bu söyleminde hareketle, ortaya çıkan her bir problemin katılımcıları stratejik düşünmeye sevk ettiği de söylenebilir. Üçüncü görüşme sorusuyla ilgili olarak KÖ 8'in görüşleri ise şu şekildedir:

Materyal gelişstirme sürecinin başından sonuna kadar hep belli bir sırayı izleyerek çalışmalarımızı gerçekleştirdik. Yapılan analizlerle elde edilen her yeni bilginin işe koşulduğu bir süreçti. Her bir grup üyesi kendi sorumluluğunun farkındaydl. Sürecin başarılı olması için ben de üzerime düşeni eksiksiz yapmaya çalıştım. (KÖ 8)

KÖ 8'in konuyla ilgili görüşlerinden hareketle DİMAG Modeli'nin birbirini takip eden belli aşamalardan oluşmasının katılımcılara sorumluluk hissi verdiği düşünülebilir. Ayrıca hem daha önce bilinenlerin hem de bu süreçte öğrenilenlerin süreçte aktif bir şekilde kullanılmasının katılımcıları yansıtıcı düşünen bireyler hâline getirdiği de söylenebilir.

\section{Sonuç ve Tartışma}

Araştırmadan elde edilen bulguların değerlendirilmesiyle şu sonuçlara ulaşılmıştır:

$\checkmark$ İlgili literatür ve konuyla ilgili uzman görüşlerinden hareketle taslak olarak ortaya konulan Disiplinlerarası Materyal Geliştirme Modeli (DİMAG) Milli Eğitim Müdürlügüünden izin al1nan okullarda uygulanmış, uygulama süreci boyunca modelin her bir aşamasının işlevselliği değerlendirilmiş ve tespit edilen eksiklikler tamamlanarak modele son hâli verilmiştir. Buna göre DİMAG, 12 aşamadan oluşan, hem süreç hem de ürün de- 
ğerlendirmeye yer veren ve disiplinlerarası iş birlikli çalışmaları gerekli kılan bir öğretim materyali geliştirme modelidir.

$\checkmark$ Deney ve kontrol gruplarında gerçekleştirilen materyal geliştirme süreçlerini gözlemleyen öğretmenlerin Öğretim Materyali Değerlendirme Formu aracılığıyla yapmış oldukları puanlamaya göre deney grubu ile kontrol grubu ortalama başarı puanları arasında deney grubu lehine anlamlı bir fark bulunmuştur. Yani DİMAG Modeli, geliştirilen öğretim materyallerinin etkililiğini artırmada etkin bir model olarak görülmüştür.

$\checkmark$ Öğretmenlere ve öğretmen adaylarına göre DİMAG Modeli, öğretim materyali geliştirme sürecine özellikle iş birlikli, disiplinlerarası ve gerçek öğrenme ortamında çalışma olanağı sunması açısından yenilik sunmaktadır. DİMAG Modeli'nin bu yapısı mesleki yeterlilikler bakımından bireylerin disiplinlerarası, iş birlikli ve planlı-programlı çalışma becerilerini geliştirmektedir. Sürece katılan bireyleri problem çözen, stratejik, eleştirel ve yansıtıcı düşünen bireyler hâline getirmektedir.

Günümüz dünyasındaki bilimsel ve teknolojik gelişmelerle birlikte artık her alanda sınırlar ortadan kalkmaya başlamış, toplumsal açıdan hayati bir değere sahip olan eğitim ortamları da bu gelişmelerden payına düşeni almıştır. Yaşanan tüm bu gelişmeler öğretim alanındaki uygulama ve alışkanlıkların değişmesinde zorlayıcı bir etken olarak belirmektedir. Artık farklı alanlarda ortaya çıkan eğitsel problemler, günümüz gelişmelerine bağlı olarak sadece o alana özgü çözüm yollarını aşarak disiplinlerarası bir çözüm yolunu gerekli kılmaktadır (Jacobs, 1989; Özkök, 2004; Gür, 2003; Yıldırım, 1996). Bu araştırma kapsamında ortaya konulan DİMAG Modeli çağdaş gelişmeler ışığında hazırlanmaya çalışılmış bir materyal geliştirme modeli olarak araştırmacıların dikkatine sunulmuştur.

Ülkemizde eğitimin en önemli sorunlarından biri okulda öğrenilenlerin gerçek hayatta uygulanamamasıdır (Kılıç, 2004; Koç, 2002). Bu sorun DİMAG Modeli'nin önem kazanmasında önemli bir etkendir. DİMAG Modeli'nin temel mantığı, öğretmen adaylarının öğretim materyali geliştirme becerilerini fakülte sınırları dışına çıkararak bizzat gerçek öğrenme ortamlarında uygulamalarını sağlamaktır. DİMAG Modeli'nin ortaya koyduğu bu anlayış, verimsizliğin ve memnuniyet- 
sizliğin olduğu bir eğitim anlayışı yerine verimli ve gerçekçi bir eğitim anlayışını önermektedir.

Çağdaş öğretim programlarının egemen olduğu günümüz eğitim anlayışı, geleneksel eğitim anlayışının etkisini sürdürdüğü ya da mevcut öğretim programlarını kilitlediği öğrenme ortamlarını reddetmektedir (Aksoy, 2003; Aydın ve Balım, 2005; Özden, 2002). İlkokul, ortaokul ve liselerde yapılandırmacı öğretim anlayışını egemen kılabilmenin yolu, öncelikle öğretmen adaylarını bu anlayış çerçevesinde yetiştirmektir. DİMAG Modeli böyle bir düşüncenin ürünü olarak ortaya çıkmıştır. Yapılan bu çalışmadan elde edilen sonuçlar, DİMAG Modeli'nin çağdaş eğitimin gereklilikleriyle örtüşür nitelikte olduğunu göstermektedir.

DİMAG Modeli'nin yaparak-yaşayarak öğrenme ortamı sağlaması ve özellikle bunu gerektirmesi araştırmanın en önemli sonuçlarından biridir. Yaparak yaşayarak öğrenmede daha çok sayıda duyu organı öğretim sürecine katılarak eğitim süreci olumlu yönde ilerletilir ve öğrenilenler daha kalıcı hâle gelir (Kaptan ve Korkmaz, 1997). Bu süreçte öğretmen adayları suni problemler doğrultusunda yapay ortamlarda materyal geliştirmek yerine, bizzat gerçek öğrenme ortamları olan okullarda gerçek hedef kitleyi dikkate alarak esnek bir program bağlamında farklı disiplinlere ait bilgi ve becerileri de işe koşarak iş birlikli materyaller geliştirmişlerdir. Dersin öğretim üyesi ve okullardaki öğretmenler rehber ve gözlemci konumundayken öğretmen adayları sürecin başından sonuna kadar aktif olma özelliklerini korumuşlardır. Öğretmen adayları süreçteki tüm kazanım ve olumsuzluklar üzerinde derinlemesine düşünceler geliştirip materyal geliştirme sürecini tüm boyutlarıyla yaşamaya çalışmışlardır (Açıkgöz, 2003). DİMAG Modeli'nin uygulaması sonrası öğretmen adaylarıyla yapılan görüşmelerde öğretmen adaylarının bu çalışmanın kendileri için öğretmenlik mesleğine başlamadan önce ciddi ve önemli bir deneyim olduğunu belirtmeleri, araştırmanın bu konudaki bulgularını destekler niteliktedir.

Her araştırmada üzerinde durulan problemin araştırmacının ilgisi çekici nitelikte olması gerekir (Perkins, 1989). DİMAG Modeli'nde araştırma problemi dersin öğretim üyesi tarafından değil, bizzat öğretmen adayı tarafından gerçek öğrenme ortamında tespit edilmektedir. Bu durum ise belirlenen problemin, araştırmacının kendi 
ilgisi bağlamında ortaya çıkmasına yardımcı olmaktadır. Araştırmacının ilgisini çeken problem durumu, çağdaş eğitimin önemli kazanımlarından biri olan üst düzey düşünme becerilerinin aktif olarak kullanılmasında önemli bir etkendir (Fogarty ve McTighe 1993; Carnine 1993; Nakhleh 1993; Paul, 1996; Halpern, 1999; Zohar, 2004). DİMAG Modeli'nde öğretmen adayı problemi tespit etmekle birlikte çözüm sürecinin merkezinde yer alarak stratejiler geliştiren, eleştirel, yaratıcı ve yansıtıcı düşünen, süreçteki olumlu ya da olumsuz tüm olasılıkları hesap eden bir rol üstlenmektedir (Zohar, 2004a). Yani DİMAG Modeli'nde öğretmen adayı sorumluluk sahibi bir birey olarak ortaya çıkmaktadır.

Yapılan bu araştırmanın bir diğer önemli kazanımı ise çalışmaya katılan öğretmen adaylarının disiplinlerarası iş birlikli çalışma becerilerini davranışa dönüştürmeleridir. $\mathrm{Bu}$ süreçte öğretmen adayları probleme farklı disiplinlerin bakış açılarından yaklaşmaya çalışmış, farklı disiplinlerle bilgi alışverişinde bulunmuş, elde etikleri bilgilerin bütünleştirilmesini sağlamış, uygulama sürecinin merkezinde yer alarak karşılaştıkları problemlere çeşitli çözüm stratejileri geliştirerek özgün bir öğretim tasarımı ortaya koymayı amaçlamışlardır (Gür, 2003; Tertemiz, 2004; Yarımca, 2011; Yıldırım, 1999). Bu şekilde yaşanan bir materyal geliştirme sürecinin hem duyuşsal, hem bilişsel hem de devinsel becerileri harekete geçirici bir etkiye sahip olduğu söylenebilir.

\section{Kaynaklar}

Açıkgöz, K, Ü. (2003). Aktif öğrenme. İzmir: Eğitim Dünyası Yayınları.

Aksoy, B. (2003). Deney yöntemi ile atmosfer basıncı konusunun öğretimi üzerine bir model. Gazi Eğitim Fakültesi Dergisi, 23(3), 207-226.

Aydın, G. ve Balım, A.G. (2005). Yapılandırmacı yaklaşıma göre modellendirilmiş disiplinlerarası uygulama: enerji konularının öğretimi. Ankara Üniversitesi Ĕ̆itim Bilimleri Fakültesi Dergisi, 2, 145-166.

Carnine D.W. (1993). Effective teaching for higher cognitive functioning. Educational Technology, 33(10), 29-33.

Cluck, N.A. (1980). Reflections in the Interdisciplinary Apporach to the Humanities. Liberal Education. 66 (1): 67-77.

Coşkun Diker , Y. ve Demirel M. (2009). Proje tabanlı öğrenme ile desteklenen disiplinlerarası öğretim yaklaşımına ilişkin bir durum çalışması. http://www.eab.org.tr/eab/oc/egtconf/pdfkitap/pdf/571.pdf adresinden 05.05.2016'da alınmıştır. 
Creswell, J. W. (2003). Research design: Qualitative, quantitative, and mixed methods approaches. (2nd ed.). Thousand Oaks, CA: Sage.

Creswell, J. W., and Plano Clark, V. L. (2014). Karma yöntem araştırmalart: Tasarımı ve yürütülmesi. (Y. Dede ve S. B. Demir, Çev. Ed.). Ankara: Anı Yayıncilık.

Demirel Ö., Seferoğlu S. S. ve Yağc1 E. (2005). Öğretim teknolojileri ve materyal geliştirme (5. Baskı). Ankara: Pegem A Yayıncılık.

Ellis, A. ve Fouts, J. (2001). Interdisciplinary curriculum: The research base. Music Educators Journal, 87, 22-26.

Fogarty, R., and McTighe, J. (1993). Educating teachers for higher order thinking: the three-story intellect. Theory into Practice, 32, 161-169.

Gür, T.M. (2003). Araştırma ve eğitiminde disiplinler arasılık, O.N. Babüroğlu (Ed.). Dicleli, Z. (Çev.) Ĕgitimin Geleceği; Üniversitelerin ve Eğitimin Değişen Paradigmast. İstanbul: Sabancı Üniversitesi Yayınları, 181-209.

Halpern, D.F. (1999). Teaching for critical thinking: helping college students develop the skills and dispositions of a critical thinker. New Directions for Teaching and Learning, , 69-74.

Hesse-Biber, S. N. (2010). Mixed methods research: Merging theory with practice. Guilford Press.

Jacobs, H.H. (1989). The growing need for interdisciplinary curriculum content. H.H. ]acobs (Ed.), Interdisciplinary eurrieulum: Design and implementation. Alexandria, VA: ASCD.

Kaptan, F. ve Korkmaz, H. (1997). Illköğretimde etkili öğretme ve ögrenme el kitabı: Illkögrretimde fen bilgisi ögrretimi. Ankara: YÖK Öğretmen Eğitimi Dizisi.

Kılıç, E. (2004). Durumlu öğrenme kuramının eğitimdeki yeri ve önemi. Gazi Eğitim Fakültesi Dergisi, 24(3), 307-320.

Koç, G. (2002). Yapılandırıcı öğrenme yaklaşımının duyuşsal ve bilişsel öğrenme ürünlerine etkisi. Yayımlanmamış doktora tezi. Hacettepe Üniversitesi Sosyal Bilimler Enstitüsü, Ankara.

Küçükahmet, L. (1999). Öğretimde planlama ve değerlendirme, İstanbul: Alkım Yayınevi.

Mcalpine, L. and Weston, C. (1994). The attributes of instructional materials. Performance Improvement Quarterly, 7(1), 19-30.

McMillan, J.H. and Schumacher, S. (2006). Research in education evidence-based inquiry. New York: Pearson Education.

Özden, Y. (2002). Eğitimde dönüşüm eğitimde yeni değerler. (4. basım). Ankara: Pegem A Yayıncilık.

Özkök, A. (2004). Disiplinlerarası yaklaşıma dayalı sanat eğitiminin yaratıcı problem çözme becerisine etkisi ve model önerisi. Yayınlanmamış Doktra Tezi. Gazi Üniversitesi Eğitim Bilimleri Enstitüsü.

Paul R. (1996). Critical thinking workshop handbook. Center for Critical Thinking, Sonoma State University, Rohnet Park, CA.

Sevim, O. (2013). Sekizinci sınıf Türkçe dersi kişisel gelişim temasının öğretiminde etkileşimli bilgisayar uygulamalarının etkileri. Yayımlanmamış doktora tezi. Atatürk Üniversitesi Eğitim Bilimleri Enstitüsü, Erzurum. 
Sevim, O. (2014). Disiplinlerarası Materyal Geliştirme Sürecinin Türkçe Öğretmen Adaylarının Öğretim Tasarımı Başarılarına ve Üstbilişsel Farkındalıklarına Etkisi. Turkish Studies - International Periodical for the Languages, Literature and History of Turkish or Turkic, 9(9), 897-913.

Sevim, O. (2015). Kuramdan uygulamaya bilgisayar destekli ögretim materyali geliştirme (Türkçe eğitimi uygulama örnekleri). Ankara: Nobel Yayıncilik.

Şahin, T. Ve S. Yıldırım (1999). Öğretim teknolojileri ve materyal geliştirme, Ankara: Anı Yayınevi.

Şimşek, N. (2002). Derste eğitim teknolojisi ve öğretim, Ankara: Kadığlu Mat.

Tertemiz, N. (2004). Çoklu Zekâ Kuram'ına göre bütünleştirilmiş etkinliklerin öğrenci başarısı üzerindeki etkisi. Ĕgitim ve Bilim, 134, 1-10.

Yalın, H. İ. (1997). Eğitim teknolojisi öğretim tasarımı, Ankara: Pegem Yayınları.

Yıldırım, A. (1966). Disiplinlerarası öğretim kavramı ve programlar açısından doğurduğu sonuçlar. Hacettepe Üniversitesi Eğitim Fakültesi Dergisi, 12, $89-94$.

Zohar, A. (2004a). Elements of teacher' pedagogical knowledge regarding instruction of higher order thinking. Journal of Science Teacher Education, 15(4), 293-312.

Zohar, A. (2004b). Higher order thinking in science classroom: Students' learning and teachers' professional development. Science \& Technology Educational Library, 22, Dorchrecht: Kluwer.

\section{Purpose}

\section{Extended Summary}

In this study an interdisciplinary material development model proposal for increasing the efficiency of teaching materials attempted to present. For this purpose, following research questions searched for answers.

*Which processes should consist of the interdisciplinary material development model (DIMAG/IMD Model) that desired to be developed?

*On which level are effectiveness of the teaching materials developed in accordance with the DIMAG/IMD Model? Model?

*What are the teachers' and prospective teachers' ideas on DIMAG/IMD

\section{Method}

As the study has both quantitative and qualitative aspects, the study conducted in accordance with the exploratory sequential pattern which is a kind of mixed methods. Mixed methods research is the use of qualitative and quantitative methods together throughout the data collection and analysis processes for understanding the research problem better and in-depth (Creswell ve Plano Clark, 2014; Hesse-Biber, 2010). Mixed methods research has kinds as explanatory 
sequential pattern, exploratory sequential pattern, transformational sequential pattern, simultaneously triangulation pattern, concurrent interwoven pattern, and simultaneous transformational pattern (Creswell, 2003). Exploratory pattern is seen as an important method as it can express quantitatively the similarities and relationships of phenomenon created with qualitative methods by participants (McMillan ve Schumacher, 2006). As these properties of exploratory pattern match up with the properties of this study exploratory sequential pattern is used.

\section{Results}

With the evaluation of the date obtained from the study these results obtained:

The DIMAG/IMD Model that was revealed as a draft has been implemented in schools with the permission received from the Directorate of Education with reference to relevant literature and expert opinions, the functionality of the each stage of model was evaluated during the application period and the determined deficiencies was completed and the model was given its last form. According to this DIMAG/IMD is a material development model that consists of 12 steps, it includes both process and evaluation of output, and it necessitates cooperative interdisciplinary studies.

According to teachers' grading, who have observed experimental and control groups material development processes, the teaching material development forms a significant difference in favor of experimental group has been found. Namely DIMAG/IMD Model has been seen as an effective model for improving the effectiveness of the developed teaching materials.

According to teachers and prospective teachers DIMAG/IMD Model offers innovation to material development process as it offers the opportunity to study collaborative, interdisciplinary, and in real learning environment. This structure of DIMAG/IMD Model is developing individuals' collaborative, interdisciplinary, and planed study skills. It turns the individuals involved in process into problem solving, strategic, critical, reflective thinking individuals.

\section{Discussion and Conclusion}

In our country one of the most important problems in education is non-use of the things learned from the school (Kılıç, 2004; Koç, 2002). This problem is an important factor for DIMAG/IMD Model to become important. The main logic of DIMAG/IMD Model is to ensure removing prospective teachers' abilities to prepare teaching materials out of faculty classes and make them perform these skills in real learning environments. The approach that DIMAG/IMD Model revealed, suggests an efficient and realistic teaching understanding instead of an insufficient and dissatisfactory understanding.

One of the most important results of this study is that the model of DIMAG/IMD provides the environment of learning through experience and especially necessitates this. During learning through experience, by being included 
Oğuzhan Sevim / Ë̈ Ĕ̆itim Fakültesi Dergisi, 18-2 (2016), 1275-1301

more sense organs in the process of teaching, the process of training is improved positively and the learned become permanent (Kaptan ve Korkmaz, 1997). In this process, instead of developing materials in artificial environments in the direction of imitation problems, prospective teachers have developed cooperative materials in the schools where there are real learning environments by considering target group and integrating different information and skills related to different disciplines within the context of flexible program. While the lecturers of the lessons and the teachers in the schools are in the guide and observer position, the prospective teachers maintain their positions as being active throughout the process. The prospective teachers improve their opinions deeply on educational attainment and negativeness in the process and try to experience the process of material development thoroughly (Aç1kgöz, 2003).In the interviews with the prospective teachers after the application of DIMAG/IMD Model, they state that for themselves this study is a serious and important experience before starting to teaching profession and this supports the study's findings in this field. 